University of Vermont

UVM ScholarWorks

Rubenstein School of Environment and Natural Rubenstein School of Environment and Natural Resources Faculty Publications

$1-1-2013$

\title{
Factors contributing to carbon fluxes from bioenergy harvests in the U.S. Northeast: An analysis using field data
}

Anna M. Mika

University of Vermont

William S. Keeton

University of Vermont

Follow this and additional works at: https://scholarworks.uvm.edu/rsfac

Part of the Agriculture Commons, Climate Commons, and the Sustainability Commons

\section{Recommended Citation}

Mika AM, Keeton WS. Factors contributing to carbon fluxes from bioenergy harvests in the US Northeast: an analysis using field data. Gcb Bioenergy. 2013 May;5(3):290-305.

This Article is brought to you for free and open access by the Rubenstein School of Environment and Natural Resources at UVM ScholarWorks. It has been accepted for inclusion in Rubenstein School of Environment and Natural Resources Faculty Publications by an authorized administrator of UVM ScholarWorks. For more information, please contact scholarworks@uvm.edu. 


\title{
Factors contributing to carbon fluxes from bioenergy harvests in the U.S. Northeast: an analysis using field data
}

\author{
ANNA M. MIKA and WILLIAM S. KEETON \\ Rubenstein School of Environment and Natural Resources, University of Vermont, 81 Carrigan Drive, Burlington, VT, 05405, \\ USA
}

\begin{abstract}
With growing interest in wood bioenergy there is uncertainty over greenhouse gas emissions associated with offsetting fossil fuels. Although quantifying postharvest carbon (C) fluxes will require accurate data, relatively few studies have evaluated these using field data from actual bioenergy harvests. We assessed $\mathrm{C}$ reductions and net fluxes immediately postharvest from whole-tree harvests (WTH), bioenergy harvests without WTH, and nonbioenergy harvests at 35 sites across the northeastern United States. We compared the aboveground forest $C$ in harvested with paired unharvested sites, and analyzed the $C$ transferred to wood products and $C$ emissions from energy generation from harvested sites, including indirect emissions from harvesting, transporting, and processing. All harvests reduced live tree C; however, only bioenergy harvests using WTH significantly reduced $\mathrm{C}$ stored in snags $(P<0.01)$. On average, WTH sites also decreased downed coarse woody debris $C$ while the other harvest types showed increases, although these results were not statistically significant. Bioenergy harvests using WTH generated fewer wood products and resulted in more emissions released from bioenergy than the other two types of harvests, which resulted in a greater net flux of $C(P<0.01)$. A Classification and Regression Tree analysis determined that it was not the type of harvest or amount of bioenergy generated, but rather the type of skidding machinery and specifics of silvicultural treatment that had the largest impact on net $C$ flux. Although additional research is needed to determine the impact of bioenergy harvesting over multiple rotations and at landscape scales, we conclude that operational factors often associated with WTH may result in an overall intensification of $C$ fluxes. The intensification of bioenergy harvests, and subsequent $C$ emissions, that result from these operational factors could be reduced if operators select smaller equipment and leave a portion of tree tops on site.
\end{abstract}

Keywords: aboveground carbon, bioenergy harvest, fossil fuel offsets, northern hardwoods, sustainable forestry, whole-tree harvest

Received 4 January 2012 and accepted 9 April 2012

\section{Introduction}

There is growing interest in managing rising atmospheric carbon dioxide $\left(\mathrm{CO}_{2}\right)$ emissions (Forster et al., 2007) through mitigation measures, including: decreasing use of fossil fuels; improving energy efficiency; increasing use of renewable fuels; and enhancing forest carbon (C) sequestration (IPCC, 2007). Forests have been a focus of those $\mathrm{C}$ mitigation efforts (Hamilton et al., 2010) due to their large capacity to sequester and store C (Nabuurs et al., 2007). However, some hypothesize that using the wood in place of fossil fuels for energy production ('bioenergy' such as combusting woodchips or pellets for electricity, heating, or combined heat and

Correspondence: William S. Keeton, tel. + 18026562518 ,

fax + 1802656 2623, e-mail: William.Keeton@uvm.edu power) could result in a net C benefit (Hall, 1997; Kroetz \& Friedland, 2008).

The short-term net $C$ outcomes associated with managing forests for bioenergy production remain uncertain. In the northern hardwood region of the northeastern U.S. wood biomass harvested for energy applications is only one of several products supplied by a logging operation. Thus, C-accounting needs to consider $\mathrm{C}$ left on site in residual biomass and $\mathrm{C}$ fluxes (i.e. net positive or negative emission of $\mathrm{C}$ to the atmosphere) into and out of the forest system, as well as C transferred to wood products, the life cycle of those products, and fossil fuel offsets (Eriksson et al., 2007; Mckechnie et al., 2011). Previous accounting studies (e.g. Manomet Center for Conservation Sciences, 2010; Nunery \& Keeton, 2010; Mckechnie et al., 2011) have been limited by a relative lack of empirical data from 
actual bioenergy harvests, requiring modeling assumptions about harvesting practices, such as whole-tree harvesting (WTH) and increased removals of low grade material. In this study, we use field data to assess whether bioenergy harvesting in the northeastern U.S. results in intensified cutting that increases net $C$ fluxes immediately postharvest.

\section{Effects of forest management on $C$ pools}

Despite the development of complex forest $\mathrm{C}$-accounting protocols in the Kyoto framework (Nabuurs et al., 2007) and by developing $\mathrm{C}$ markets (American Carbon Registry, 2010; California Air Resources Board, 2010; Verified Carbon Standard, 2010), some aspects of forest management effects on $C$ dynamics remain in debate. The issue is how to rigorously account for above and belowground forest C pools, C fluxes through the wood products stream, and avoided emissions (i.e. 'offsets') associated with substituting wood for other building materials and fossil fuels (Eriksson et al., 2007).

Depending on the assumptions made about each of these and their relative weight in the C-accounting, studies can come to very different conclusions about forest management. For instance, many studies have determined that less intensive harvesting practices result in the greatest net increase in C storage (Harmon et al., 1990; Harmon \& Marks, 2002; Swanson, 2009; Nunery \& Keeton, 2010). Other studies have concluded exactly the opposite, stressing substitution effects (Eriksson et al., 2007; Davis et al., 2009; Routa et al., 2011), which are market-driven and may be difficult to predict. For instance, Eriksson et al. (2007) concluded that, in some cases, intensive harvesting combined with substitution of bioenergy for fossil fuels may result in the greatest net emissions reductions due to accumulation of fossil fuel offsets. Under their modeling framework fertilizing, harvesting slash and stumps, and substituting wood for construction material and coal had a greater $C$ benefit than retaining residues and offsetting natural gas (Eriksson et al., 2007). Others have questioned the assumptions regarding substitution effects (Schulze et al., 2012). Accurate accounting, and to some extent resolution of the on-going debate about forest bioenergy (Harmon \& Marks, 2002; Searchinger et al., 2009; Mckechnie et al., 2011), will depend on the advent of real data.

In terms of bioenergy harvesting, a critical consideration is the extent to which operations might result in increased $\mathrm{C}$ removals through intensified harvesting practices (Zanchi et al., 2011), such as WTH. Similarly, accounting for fossil fuel offsets requires information about the types of fuels replaced, for which accurate data are not consistently available. As demand for wood bioenergy increases (Briedis et al., 2011a; Munsell et al., 2011; Zanchi et al., 2011), understanding the $C$ trade-offs of different forest management approaches, including those specific to bioenergy (e.g. WTH), will become increasingly important.

Quantifying the net $\mathrm{C}$ effects of forest management practices, including bioenergy harvesting, requires understanding the pathways and rates of changes in forest $\mathrm{C}$ pools. This may be particularly important for WTH because it involves removal of large amounts of aboveground biomass in whole trees (see Fig. 1), including tree tops and limbs (Johnson \& Curtis, 2001). This differs from stem-only conventional harvesting where only roundwood is taken off site (Vanguelova et al., 2010). WTH is an economical and efficient way to harvest residues, including roundwood on upper tree stems (Briedis et al., 2011a; Lippke et al., 2011), which otherwise is considered unmerchantable and left on site. Chipping this material and using it to generate energy provides an additional revenue source.

In addition to impacting aboveground live tree C pools, WTH may increase the intensity of the harvest and impact the dead $C$ pools, including snags and downed wood (Briedis et al., 2011a). Timber harvesting often disproportionally impacts dead C pools through effects on input rates, species composition, and size distribution of downed coarse woody debris (DCWD; Harmon et al., 1986). WTH can increase dead wood C impacts through removal of tree crowns and upper stems and by harvesting dead and low vigor trees, impairing DCWD recruitment (Lattimore et al., 2009), and altering the quantity and temporal dynamics of C storage in the DCWD pool (Harmon et al., 1986). Although C is emitted through decomposition (Parikka, 2004; Johnson, 2009; Searchinger et al., 2009), the overall dead wood pool can accumulate for long periods (Harmon, 2001), ultimately accounting for $>10 \%$ of total aboveground $\mathrm{C}$ storage in late-successional northern hardwood-conifer forests (Keeton et al., 2011). Removal of DCWD recruitment sources over multiple rotations, thus, may result in a long-term reduction in forest stand C (Harmon et al., 1990; Harmon \& Marks, 2002). Therefore, assessing the impacts of bioenergy harvesting on dead wood pools, in addition to aboveground live tree $\mathrm{C}$ pools, is important for understanding the $\mathrm{C}$ impacts of bioenergy harvests.

\section{Carbon mitigation through bioenergy harvests}

Some have assumed that bioenergy is 'carbon-neutral' because harvested $\mathrm{C}$, which is combusted and emitted as $\mathrm{CO}_{2}$, is later sequestered through forest regrowth (Kroetz \& Friedland, 2008). However, a developing literature has questioned many of the fundamental assumptions in this 

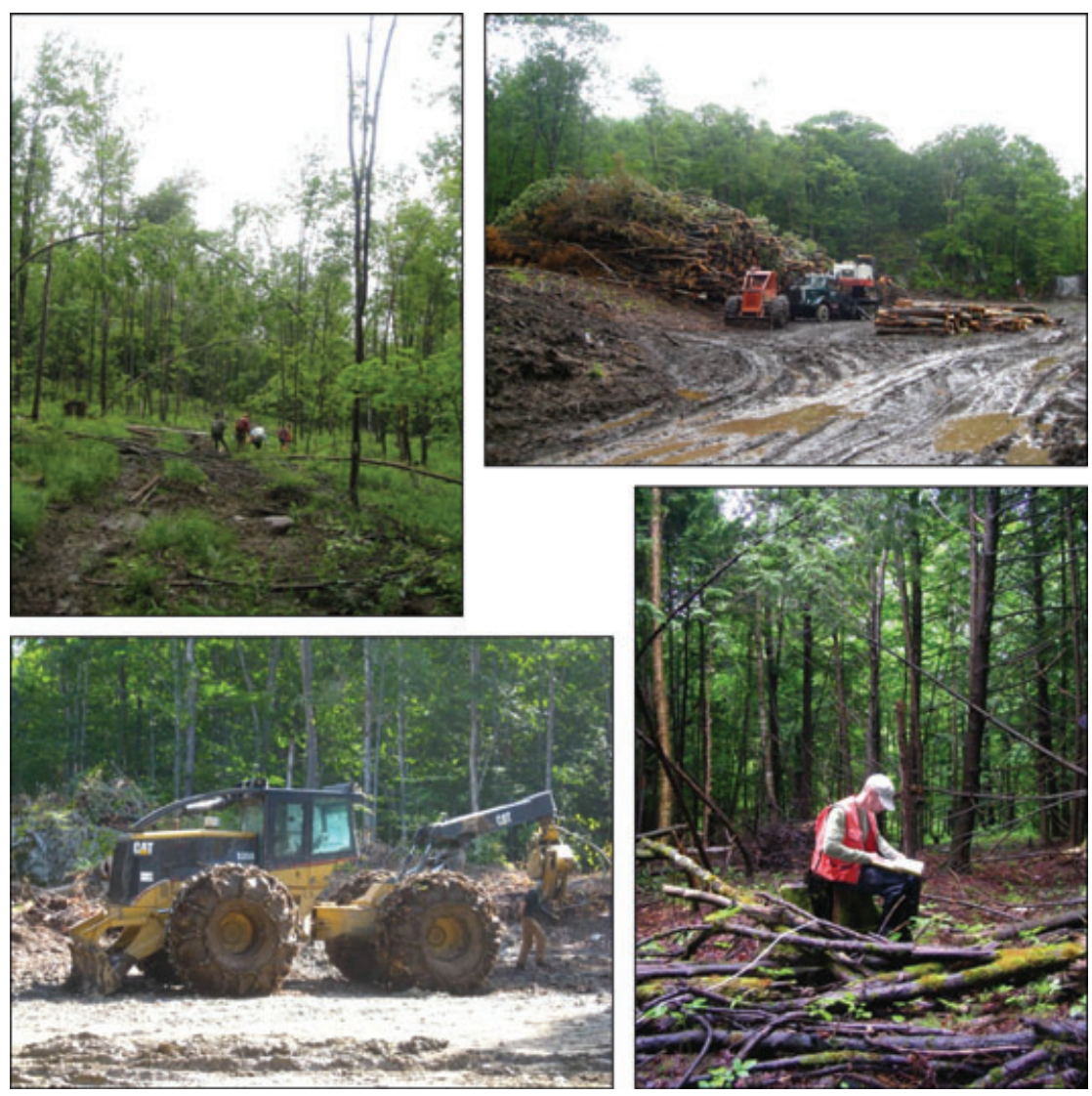

Fig. 1 An example of a 'heavy' harvest in our dataset that employed WTH with single-tree selection, both a grapple and a cable skidder, and a shear (top left). This site resulted in a $-101 \%$ difference in forest stand $\mathrm{C}$ from reference unharvested to harvested stand. Tree tops left on landing at a WTH site waiting to be chipped (top right). An example of a 'light' WTH that used single-tree selection, a cable skidder only, and a shear with a chainsaw (bottom right). This harvest had more tree tops (and of larger diameter) left on site and resulted in a $-39 \%$ difference in forest stand C postharvest. A CAT 535B grapple skidder used at a site in our dataset (bottom left). (Photo credit: C.E. Littlefield, except bottom right photo by A.M. Mika).

argument (Johnson, 2009; Searchinger et al., 2009; Mckechnie et al., 2011; Zanchi et al., 2011; Gunn et al., 2012; Schulze et al., 2012). Important uncertainties remain regarding the temporal dynamics of $C$ fluxes associated with bioenergy use. One of these is the timeframe over which an initial C 'debt,' or C flux, might be compensated by a $C$ 'dividend' from fossil fuel offsets and forest regrowth (Mckechnie et al., 2011; Routa et al., 2011; Zanchi et al., 2011).

Another key consideration is how these dynamics will play out at landscape scales as a function of harvests scheduled or staggered across time and space (Gunn et al., 2012). There may be compensatory effects at landscape scales, possibly equilibrating $\mathrm{C}$ emissions and $C$ uptake across multiple stands harvested at different time schedules (Ryan et al., 2010). However, there may nevertheless be a permanent flux of $\mathrm{C}$ off the landscape if overall harvesting intensity increases. This would result in lower net average landscape $C$ storage that may not be compensated by fossil fuel offsets. The complex question of whether greater reliance on wood bioenergy reduces $C$ emissions would depend on the rate at which the loss of landscape $\mathrm{C}$ storage is compensated by avoided fossil fuel emissions. Our study addresses the former, using field data to determine whether bioenergy harvests are in fact intensifying $\mathrm{C}$ removals and increasing the net $C$ flux, and thus might have the potential to reduce net landscape $C$ storage.

The intensity of bioenergy harvests in the northeastern U.S. may vary considerably, by factors such as the area, volume, and the type of material harvested. Currently, the main source of bioenergy in developed countries is primary (i.e. harvests producing logs, sawlogs, pulp, veneer, and woodchips) and secondary (i.e. harvests producing finished or semifinished products with no primary products) wood product operations (Lattimore et al., 2009). The scale varies from small, familyowned firewood operations to large industrial energy plantations, and material can be generated from thinning operations, residues and mill waste, bioenergy 
plantations and agro-forestry operations, and fuel wood gathered from urban areas (Lattimore et al., 2009). Although there is concern that rising demand for bioenergy will intensify removals of dead wood and harvesting residues (Briedis et al., 2011a), some bioenergy harvesting may improve stand stocking and stem quality by removing low grade material. For example, thinning from below (termed 'stand improvement cutting'), sometimes used for bioenergy harvesting, can increase merchantable volume production and rates of $\mathrm{C}$ uptake (Hoover \& Stout, 2007), although there is still an initial flux of C after the disturbance (Harmon, 2001).

In this study we evaluated the effects of a range of bioenergy harvesting types and intensities on postharvest aboveground forest $C$ storage and net $C$ fluxes. The study objectives were to: (1) determine whether bioenergy harvests, especially those using WTH, are more intensive than nonbioenergy harvests by comparing their respective immediate postharvest changes in aboveground forest $\mathrm{C}$ pools, (2) evaluate whether bioenergy harvests had greater total net $C$ emissions than harvests without bioenergy as a product, and (3) assess which site-specific and operational variables most strongly predict net $\mathrm{C}$ outcomes.

\section{Materials and methods}

\section{Study site}

Our study area was within the northern hardwood region of northeastern U.S., focusing on northern New York, Vermont, and New Hampshire (Fig. 2). The climate is humid continental (i.e. moist temperate) with even distribution of precipitation throughout the year, cold winters, and warm to hot summers. The topography is characterized by postglacial valleys, plateaus, hills, and the Green, White, and Adirondack mountain ranges. Alluvial sediments and glacial tills created fertile edaphic conditions, consisting mostly of the well-drained and partially loamy Tunbridge soils series. Vegetation is predominantly mature (50-100 years old), even or multiaged northern hardwood or northern hardwood-conifer forests. Dominant species include Acer saccharum (sugar maple), Fagus grandifolia (American beech), Betula alleghaniensis (yellow birch), and Tsuga canadensis (eastern hemlock) with significant components of Fraxinus americana (American white ash), Acer rubrum (red maple), and Pinus strobus (eastern white pine).

From a request sent to 115 professional foresters in the region, we identified 43 recently harvested candidate sites to which we applied selection criteria; of these 35 met our requirements and were included in the study (Table 1). The selection criteria included the following: public or private ownership; harvested within 3 years; naturally regenerated stands (no plantations); low to mid elevation (610 m maximum); moderate to high site productivity (sugar maple site class 1-3); and presence of an unharvested adjoining portion of each stand. Harvests were not selected based on the type of operation (e.g. whole-tree vs. nonwhole-tree harvest), but rather were a representative sample of the harvest activity occurring in our study region. We specifically excluded clear-cutting operations in our study because most harvests in the Northeast are partial harvests (Sader \& Legaard, 2008) and structural retention considerations for clear-cutting are fundamentally different. Each harvested site was paired with an immediately adjacent unharvested portion of the stand of similar ecological characteristics (i.e. overstory composition, structure, and disturbance history) as a reference for estimating preharvest conditions. Our study included sites, which had been harvested for wood products in

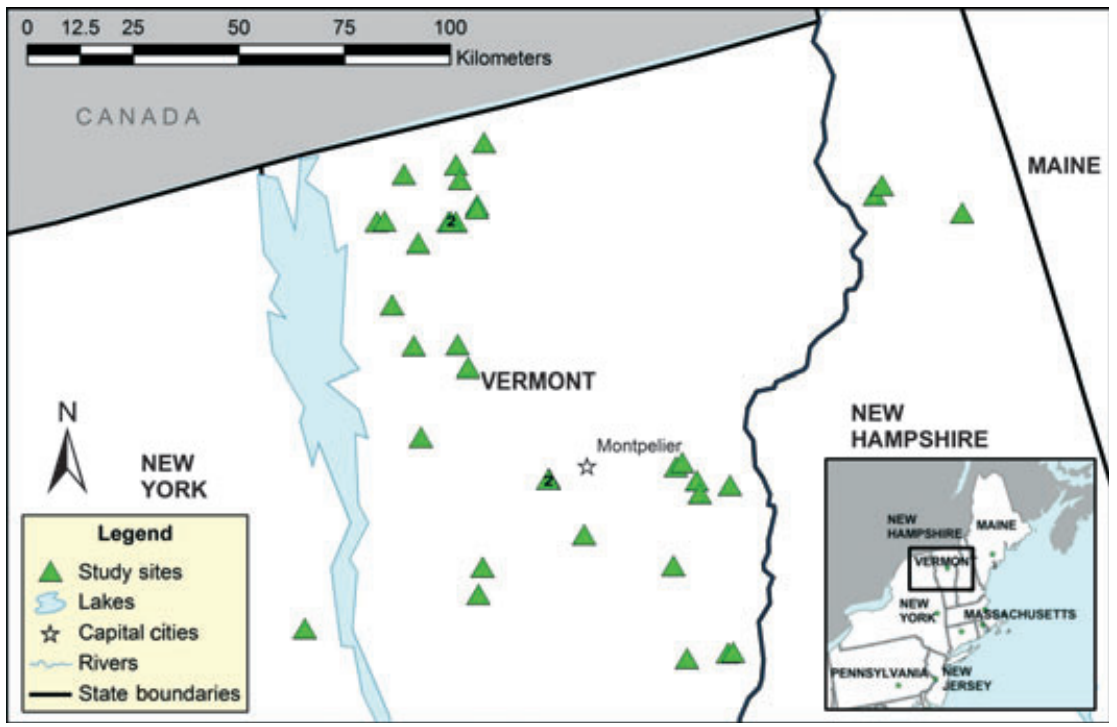

Fig. 2 Map of the study sites $(N=35)$. Where two sites overlap due to close proximity, a ' 2 ' indicates that there are 2 properties sampled in that location. 


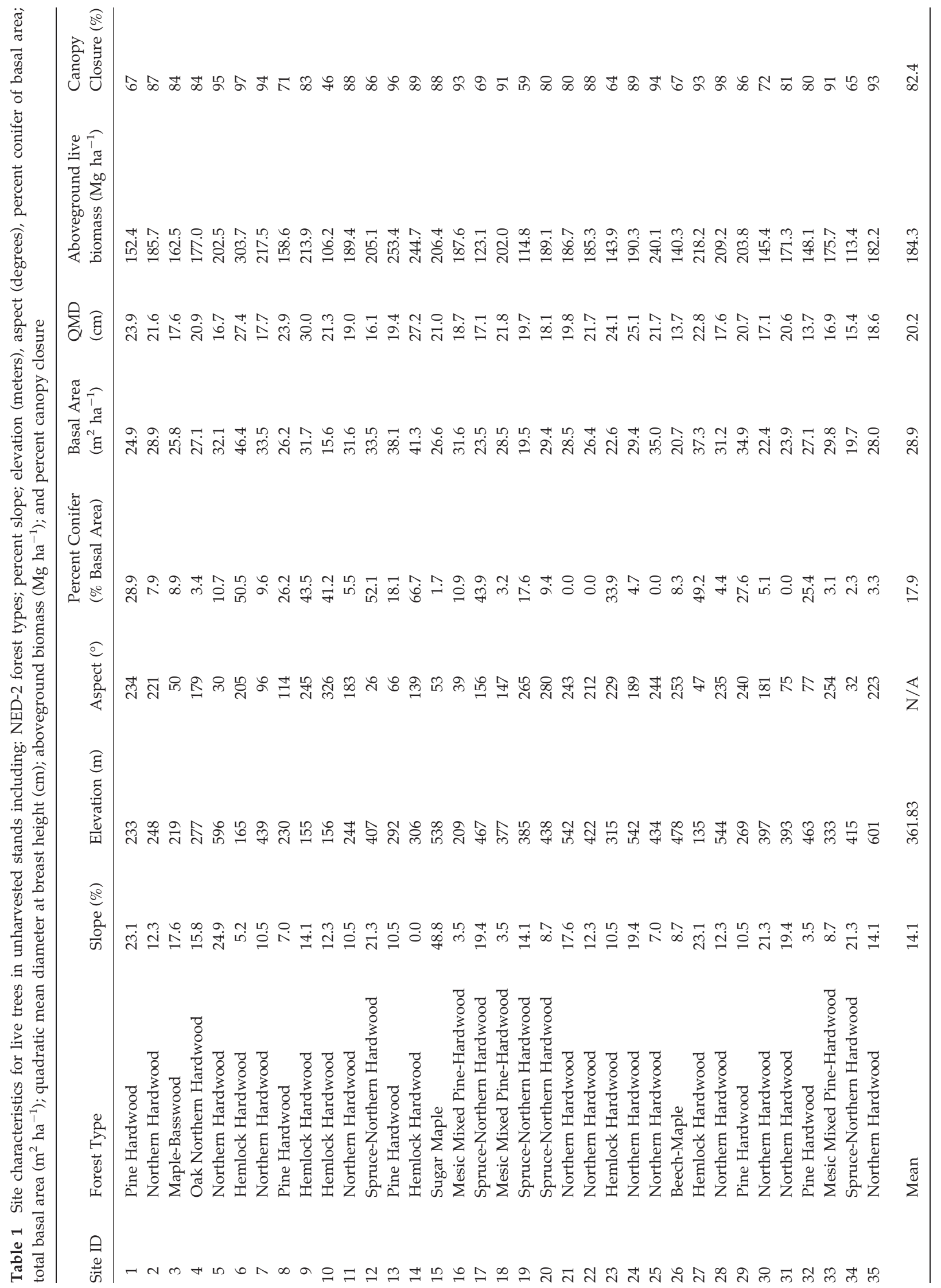

(C) 2012 Blackwell Publishing Ltd, GCB Bioenergy, doi: 10.1111/j.1757-1707.2012.01183.x 
addition to bioenergy with and without WTH. The sites ranged in age from 40 to 130 years of age; however, with partial harvesting common in the study area, most stands are multiaged. The final set included 25 sites harvested for bioenergy using WTH ('bioenergy WTH'), 4 sites harvested for bioenergy without WTH ('bioenergy non-WTH'), and 6 sites harvested for conventional products without bioenergy ('nonbioenergy'; Table 2). The unequal sample sizes are an artifact of both the sites available and a trend toward greater use of WTH in the study area. Finally, using a standardized survey, we collected information about ownership, certifications, management objectives, silvicultural treatments, harvesting and skidding machinery, end-user(s) of bioenergy, physical characteristics, and other operational variables from the foresters and contractors involved with each logging operation (Table 2).

\section{Field data collection}

We inventoried forest structure and composition with 4-7 variable radius prism plots (2.3 metric basal area factor) at each site, the number being proportionate to site area. The plots were randomly placed using a random number table to establish compass bearing and distance from a central point of origin, ensuring that sample plots were well distributed. Trees $>5 \mathrm{~cm}$ at breast height $(1.37 \mathrm{~m})$ were inventoried including diameter at breast height (dbh), species, and live or dead status. For dead trees, aka 'snags,' the decay class (ranging from 1 to 9) was recorded and the height measured using an Impulse 200 laser range finder (Laser Tech, Inc., Englewood, CO, USA).

At the location of each prism plot, we also placed a fixed area plot centered on the same location. We used the line intercept method (Van Wagner, 1968) with transect lengths of 35.7 and $25.24 \mathrm{~m}$ to inventory DCWD and fine woody debris (FWD), respectively. Trees leaning below a $45^{\circ}$ incline from the ground, $\geq 10 \mathrm{~cm}$ in diameter at point of intercept, and $\geq 1 \mathrm{~m}$ in length were counted as DCWD. We recorded the diameter and decay stage (1-5) following Sollins (1982) for each piece of DCWD at the point of intercept. FWD was considered to be any limb between 2 and $10 \mathrm{~cm}$ in diameter at intercept and $\geq 20 \mathrm{~cm}$ in length. The diameter and angle to the ground of each piece of FWD was measured with a clinometer. Angles were recorded in $5^{\circ}$ increments to be used in the Woodall \& Williams (2005) volume equations.

\section{Data processing}

Inventory data were input into the Northeast Ecosystem Management Decision model, NED-2 (Twery et al., 2005) to generate structural and compositional biometrics, including aboveground biomass of live trees, calculated allometrically using the Jenkins et al. (2003) equations. The Jenkins et al. (2003) equations have been widely used in other studies (e.g. see Fredeen et al., 2005; Keeton, 2006; Lamsal et al., 2011; Van Tuyl et al., 2005). We computed the volume, biomass, and C content of the four pools (aboveground live, aboveground dead, DCWD, and FWD) as described below. We chose not to include belowground $C$ due to lag times in soil $C$ responses and variability associated with silvicultural treatments, particularly partial harvests, found by previous research (Yanai et al., 2003; Jandl et al., 2007; Nave et al., 2010).

The volume of DCWD by decay stage was determined for each site following Van Wagner (1968) as modified by Woodall \& Williams (2005). DCWD biomass was calculated by multiplying the volume of each log by the specific gravity corresponding to decay stage from Harmon et al. (2008). As the species of each piece of DCWD could not be determined consistently, a weighted average of the specific gravities (using Harmon et al., 2008) for each decay class was used. The weighted average was computed based on percent basal area by species for all live and dead trees at each site. The C in the DCWD pool at each site was then calculated by multiplying the total biomass by the following $C$ values by decay stage: 0.499 (decay stage 1 ); 0.488 (decay stage 2); 0.486 (decay stage 3 ); 0.518 (decay stage 4); and 0.501 (decay stage 5; Harmon et al., 2008). The average volume of FWD was determined by taking the mean of the angles of each piece of FWD for each plot and using equations from Woodall \& Williams (2005). The biomass and C in the FWD pool at each site was calculated in the same manner as for DCWD. As the decay stage and species of each piece of FWD was not identified, the average $C$ content of the five decay stages (i.e. 0.498) was used for all pieces of FWD.

Finally, snag volumes were computed using Honer et al. (1983) species-specific equations, which use both the diameter and top height measurements. We used Honer et al.'s (1983) species-specific tapering functions to convert from our dbh measurements at $1.37 \mathrm{~m}$ height to the $1.30 \mathrm{~m}$ height assumed in the volume equations. Tapering functions for morphologically similar species were used in some cases, as suggested by Townsend (1996). We converted from volume to biomass and C content, using decay stage (1-9) specific conversion factors, according to Harmon et al. (2008). For snags of unknown species, we used a weighted specific gravity based on the percent basal area of live trees and identified snags.

\section{Fossil fuel offsets, wood products, and indirect emissions}

We determined the net $\mathrm{C}$ outcomes of the harvests in our dataset, accounting for: (1) offsetting fossil fuels with bioenergy; (2) flux of C from the processing of logs into wood products; (3) C transferred to wood products; and (4) indirect emissions from harvesting equipment, transport to power plant/mill, and processing of woodchips, wood products, and fossil fuels. For harvests that produced bioenergy we assessed the $C$ fluxed from energy generation from wood, and thus was assumed to have offset or prevented fossil fuel emissions. The amount of fossil fuels, and therefore C, that was offset was calculated based on the specific types of energy generated from the harvests in our dataset. The fossil fuel used for heating and combined heat and power was assumed to be natural gas, which has a heating content of 0.12 GJ per gallon (California Air Resources Board, 2010). For electricity, it was assumed that the bioenergy replaced the U.S. Northeast electricity grid (Table 3; Rothschild et al., 2009). In addition to the $C$ emitted from combustion, we calculated the indirect emissions from extraction and processing of fossil fuels, assuming that these 'well-to-tank' emissions 
Table 2 Independent variables used in the Classification and Regression Tree (CART) multivariable analysis, their classification as categorical or numeric, levels if categorical, and number of sites for each classification. Certifications included in this study were: Northeast Organic Farming Association (NOFA; http://www.nofa.org/index.php); Vermont Family Forests (http://www.familyforests.org); Tree Farm (http://www.treefarmsystem.org); and Forest Stewardship Council (FSC; http://www.fsc.org). Other nonformal certifications included: Vermont Land Trust (VLT; http://www.vlt.org); Biomass Crop Assistance Program (BCAP; http://www.fsa. usda.gov/FSA/webapp?area=home\&subject=ener\&topic=bcap); and easements held by the USDA Forest Service (FSE)

\begin{tabular}{|c|c|c|c|}
\hline Independent Variable & Type & Levels & Number of Sites \\
\hline \multirow[t]{2}{*}{ Tenure } & \multirow[t]{2}{*}{ Categorical } & Public & 6 \\
\hline & & Private & 29 \\
\hline \multirow[t]{3}{*}{ Ownership } & \multirow[t]{3}{*}{ Categorical } & Family/Co-op & 23 \\
\hline & & State & 6 \\
\hline & & Corporate/Institutional & 6 \\
\hline \multirow[t]{2}{*}{ Certifications } & \multirow[t]{2}{*}{ Categorical } & No: None, VLT, BCAP, FSE & 23 \\
\hline & & $\begin{array}{l}\text { Yes: NOFA, VT Family Forests, } \\
\text { Tree Farm, FSC }\end{array}$ & 12 \\
\hline \multirow[t]{2}{*}{ Current Use } & \multirow[t]{2}{*}{ Categorical } & Yes & 22 \\
\hline & & No & 13 \\
\hline \multirow[t]{2}{*}{ Current Management } & \multirow[t]{2}{*}{ Categorical } & Sugarbush & 7 \\
\hline & & Forestland & 28 \\
\hline \multirow[t]{2}{*}{ Marking by Professional Forester } & \multirow[t]{2}{*}{ Categorical } & Yes & 28 \\
\hline & & No & 7 \\
\hline \multirow[t]{4}{*}{ Season of Harvest } & \multirow[t]{4}{*}{ Categorical } & Summer & 10 \\
\hline & & Summer and Winter & 4 \\
\hline & & Fall & 4 \\
\hline & & Winter & 17 \\
\hline \multirow[t]{3}{*}{ Type of Harvest } & \multirow[t]{3}{*}{ Categorical } & Bioenergy WTH & 25 \\
\hline & & Bioenergy non-WTH & 4 \\
\hline & & Non-Bioenergy & 6 \\
\hline \multirow[t]{6}{*}{ Primary Treatment } & \multirow[t]{6}{*}{ Categorical } & Thinning from above & 8 \\
\hline & & Thinning from below & 10 \\
\hline & & Single-tree selection & 6 \\
\hline & & Shelterwood & 4 \\
\hline & & Group selection & 4 \\
\hline & & Uneven aged combo & 3 \\
\hline \multirow[t]{7}{*}{ Secondary Treatment } & \multirow[t]{7}{*}{ Categorical } & Thinning from above & 2 \\
\hline & & Thinning from below & 8 \\
\hline & & Single-tree selection & 1 \\
\hline & & Group selection & 4 \\
\hline & & Salvage logging & 2 \\
\hline & & Scarification & 2 \\
\hline & & None & 16 \\
\hline \multirow[t]{4}{*}{ Skidder } & \multirow[t]{4}{*}{ Categorical } & Grapple skidder & 15 \\
\hline & & Cable skidder & 10 \\
\hline & & Both cable and grapple Skidders & 7 \\
\hline & & None (bulldozer/forwarder only) & 3 \\
\hline \multirow[t]{3}{*}{ Cutting Equipment } & Categorical & Shear & 20 \\
\hline & & Chainsaw & 10 \\
\hline & & Shear/chainsaw & 5 \\
\hline Chipping Location for & Categorical & Landing & 25 \\
\hline whole-tree harvested sites & & Electric power plant & 4 \\
\hline & & N/A (nonbioenergy) & 6 \\
\hline Bioenergy ( $\%$ by Volume) & Continuous & Numeric & 29 \\
\hline Buyer/End User of Bioenergy & Categorical & Municipal & 24 \\
\hline & & Municipal/schools & 2 \\
\hline & & Municipal/pulp-mill or pulp-mill & 3 \\
\hline & & N/A (nonbioenergy) & 6 \\
\hline
\end{tabular}


Table 3 Energy conversion factor (GJ ton ${ }^{-1}$ ) for bioenergy (GJ ton ${ }^{-1}$ ) and fossil fuels (GJ gallon ${ }^{-1}$ ), and emission factors $\left(\mathrm{Mg} \mathrm{CO}_{2} \mathrm{e} \mathrm{GJ}{ }^{-1}\right)$ for electricity, thermal, and combined heat and power

\begin{tabular}{|c|c|c|c|c|c|}
\hline \multirow[b]{2}{*}{$\begin{array}{l}\text { Type of Energy } \\
\text { Generated }\end{array}$} & \multirow[b]{2}{*}{$\begin{array}{l}\text { Assumed } \\
\text { Efficiency (\%) }\end{array}$} & \multicolumn{2}{|c|}{ Energy Content (GJ) } & \multicolumn{2}{|c|}{$\begin{array}{l}\text { Emission Factor } \\
\left(\mathrm{Mg} \mathrm{CO}_{2} \mathrm{e} \mathrm{GJ}{ }^{-1}\right)\end{array}$} \\
\hline & & $\begin{array}{l}\text { Bioenergy } \\
\text { (per ton) }\end{array}$ & $\begin{array}{l}\text { Fossil Fuel } \\
\text { (per gallon) }\end{array}$ & Bioenergy & Fossil Fuel \\
\hline Electricity & $30^{*}$ & $2.40^{\dagger}$ & $\mathrm{N} / \mathrm{A}^{\ddagger}$ & $0.76^{\S}$ & $0.11^{\natural}$ \\
\hline Thermal & $80^{* *}$ & $6.40^{\dagger}$ & $0.09^{\dagger \dagger}$ & $0.29^{\S}$ & $0.08^{\dagger \dagger}$ \\
\hline $\begin{array}{l}\text { Combined Heat } \\
\text { and Power }\end{array}$ & 55 (80 overall) & $4.40^{\dagger}$ & $0.06^{\dagger \dagger}$ & $0.42^{\S}$ & $0.12^{\dagger \dagger}$ \\
\hline
\end{tabular}

*Midpoint of 20-40\% electricity efficiency (Demirbas, 2001).

$\dagger$ Lower heating value of 8 GJ per wet ton (Demirbas, 2001).

$\ddagger$ The Northeast (NEWE) grid is made up of various sources of fuel; therefore, 1 GJ per gallon value is not appropriate.

§ased on assumption that $50 \%$ of the mass of wood is C (Birdsey, 1992).

INEWE eGrid emission factor (Rothschild et al., 2009).

**Direct combustion with 20\% loss (Demirbas, 2001).

$\dagger$ Natural gas (California Air Resources Board, 2010).

$\$$ TCombined heat and power has $80 \%$ overall efficiency: $30 \%$ efficiency for electric and $50 \%$ for heating.

account for $15 \%$ of total ('well-to-wheels') emissions from fossil fuel use (Hudiburg et al., 2011).

The amount of bioenergy generated from each harvest was determined using two methods, depending on available information. The weight of chips in metric green tons, as reported at each harvesting operation, was used when available; otherwise, the volume of chips was calculated based on the total biomass harvested, multiplied by the percent volume allocated to bioenergy. We assumed a coefficient of 0.05 for indirect emissions from woodchips from harvesting, transporting, and manufacturing (Hudiburg et al., 2011). The coefficient assumes a median trip distance of $81 \mathrm{~km}$ (Evans \& Finkral, 2009), which corresponded well to our calculated average trip distance of $79 \pm 56 \mathrm{~km}$. Chipping is highly efficient with minimal losses; therefore, we did not incorporate these losses. We assumed the woodchips were not dried, as is common practice in the Northeast. The energy conversion factors for both bioenergy and fossil fuels were computed for electricity, heating, and combined heat and power (Table 3). The C transferred to wood products was determined based on the information supplied by the foresters at each site. The indirect emissions that result from the conversion into wood products were based on life cycle data for northern hardwoods presented in Smith et al. (2006). We assumed that immediately postharvest $61.4 \%$ of the hardwood sawlogs and firewood were in use, $56.9 \%$ of the softwood sawlogs were in use, $51.3 \%$ of the softwood pulp, and $65.0 \%$ of the hardwood pulp were in use (Smith et al., 2006). The remaining $\mathrm{C}$ in unutilized residues is emitted during processing or from decomposition of tree parts (e.g. roots) left in the forest (Smith et al., 2006). The harvest and transport coefficients of 0.009 and 0.003, respectively, were used (Hudiburg et al., 2011). All C transferred to wood products was calculated on a per hectare basis to correspond to the units of the emissions from energy generation. When records (e.g. mill receipts) for percent volume by product type were not available, we converted the estimated weights of the products to volume. As we did not have data on milling residues used for energy generation at the mill, we did not include this in our analysis. However, as explained below, we did account for woodchips used at mills. Furthermore, we did not treat firewood as a bioenergy product because cordwood is a traditional product from nonbioenergy harvests that we were comparing against, although we recognize that firewood is sometimes considered a type of energy wood. To determine whether this affected our results, we also reran our analysis treating firewood as bioenergy (in the same way as the heating calculations), but did not reclassify sites.

We compared the C fluxed and stored in various pools between types of harvests. To compare harvested sites with their paired reference sites, we used a 'percent difference' metric modified from Westerling et al. (2006), and calculated as:

$$
\left(\left(x_{1}-x_{2}\right) / \bar{x}_{1,2}\right)
$$

where $x_{1}$ represents a pool of $\mathrm{C}$ at a harvested stand, $x_{2}$ is the same pool in the paired unharvested stand, and $\bar{x}_{1,2}$ is the mean of the two. This metric was calculated for all fluxes and C pools and used to eliminate distorted or misleading values that can occur in percent change or contrast data. It was also used so that increases in a $C$ pool from 0 could be calculated; percent change would calculate this as 'undefined'. The percent difference metric normalized relative contrasts (harvested vs. reference) across all sites, and thus provided a surrogate for estimating pre to postharvest changes.

Finally, to calculate the net flux of $C$ from each type of harvest, we used the following formula to estimate stored $(+)$ and emitted (-) C:

$$
\begin{aligned}
\bar{C}_{\text {Flux }}= & \bar{C}_{\text {Live }}+\bar{C}_{\text {Snag }}+\bar{C}_{C W D}+\bar{C}_{F W D}+\bar{C}_{W P \_s t o r e d}-\bar{C}_{W P \_ \text {emitted }} \\
& -\left(\bar{C}_{\text {Bionergy }}-\bar{C}_{\text {Offset }}\right)
\end{aligned}
$$

where WP represents wood products. The emissions from bioenergy and fossil fuels included both direct and indirect emissions. 


\section{Statistical analysis}

We choose nonparametric tests for our data analysis due to departures from normality for some variables, detected using the Shapiro-Wilk normality test. All statistical tests were performed in JMP 9.0.0 for Windows (SAS Institute Inc, 2010) and considered significant at $\alpha=0.05$. C pools were compared between paired harvested and unharvested stands for each type of harvest, as well as for all the sites combined, using the Wilcoxon Signed Rank test. This was followed by the Wilcoxon Rank Sum test with post hoc multiple comparisons for all percent difference tests.

Lastly, we ran a multivariate analysis in S-Plus 8.2 for Windows (TIBCO Software Inc, 2008) to identify the independent variables most predictive of net postharvest C fluxes (Table 2). We used a Classification and Regression Tree (CART) analysis to evaluate which variables contributed the most to determining postharvest net $\mathrm{C}$ outcomes. The CART is a robust nonparametric statistical method that partitions the variance (termed 'deviance') in a dependent variable based on categorical or numeric independent variables (De'ath \& Fabricius, 2000). It is a powerful tool for ecological analysis because of its ability to accommodate nonlinear relationships, high-order interactions, and missing values (De'ath \& Fabricius, 2000). We used CART not to establish definitive threshold values for predicting responses in independent variables, but rather to understand the relative predictive strength of multiple independent variables (De'ath \& Fabricius, 2000; Keeton \& Franklin, 2005; Keeton et al., 2007).

\section{Results}

\section{Effects of harvesting on forest $C$ pools}

Values for many of the $\mathrm{C}$ pools ranged widely both within and among treatment categories (Table 4). For all harvest types, the total mean $\mathrm{C}$ in the unharvested stands ranged from 68.83 to $159.95 \mathrm{Mg} \mathrm{ha}^{-1}$, whereas it was $40.22-123.81 \mathrm{Mg} \mathrm{ha}^{-1}$ in the harvested stands. Across all sites the largest aboveground pool of $\mathrm{C}$ was in the live trees, ranging from $75.4-97.7 \%$ and 67.3-96.2\% of total stand $C$ in the unharvested and harvested stands, respectively. The snags comprised a very small portion of the total $\mathrm{C}$ on average, accounting for less than $7 \mathrm{Mg} \mathrm{C} \mathrm{ha}^{-1}$ in the unharvested stands and $2.3 \mathrm{MgC} \mathrm{ha}{ }^{-1}$ in the harvested stands (with ranges of $0.04-6.9 \%$ and $0-5.0 \%$ of total stand $C$, respectively). Of the total forest C, DCWD pool varied considerably in both unharvested (1.3-21.0\%) and harvested (2.3-26.0\%) stands. The FWD pool was proportionately very small across all sites, holding only $0.6-2.3 \%$ of total stand $C$ in the unharvested stands and $1.4-6.6 \%$ in the harvested stands.

Comparisons of C levels between paired harvested and unharvested reference sites revealed statistically significant differences in aboveground standing pools and some changes in inputs of dead wood pools (Table 5). There were significantly higher amounts of $C$ in aboveground live trees $(P<0.0001)$, snags $(P<0.001)$, and total $C(P<0.0001)$ in the unharvested stands compared with the paired harvested stands (Table 5). There was more $C$ in the FWD pool postharvest $(P<0.0001)$ compared with unharvested sites, but no statistically significant difference in the DCWD $\mathrm{C}$ pool (Table 5). Comparing harvest types showed that bioenergy WTH had less $C$ in the snag pool than paired unharvested sites $(P<0.01)$. This was not the case for bioenergy non-WTH and nonbioenergy sites (Table 5).

Furthermore, statistical tests using the percent difference metric (comparison of unharvested to harvested $C$ pools) yielded a different perspective than those using absolute values. Comparing the percent differences in each of the aboveground forest $C$ pools as well

Table 4 Residual mean carbon content $\left(\mathrm{Mg} \mathrm{C} \mathrm{ha}^{-1}\right)$ and percent differences with standard error comparing aboveground $\mathrm{C}$ pools for harvested and unharvested stands immediately postharvest for three categories of harvest, including whole-tree harvesting (WTH)

\begin{tabular}{|c|c|c|c|c|c|}
\hline & $\begin{array}{l}\text { Aboveground } \\
\text { Live Tree }\end{array}$ & $\begin{array}{l}\text { Aboveground } \\
\text { Dead Tree }\end{array}$ & DCWD & FWD & $\begin{array}{l}\text { Total } \\
\text { Aboveground }\end{array}$ \\
\hline \multicolumn{6}{|l|}{ Non-Bioenergy } \\
\hline Harvested $\left(\mathrm{Mg} \mathrm{C} \mathrm{ha}^{-1}\right)$ & $71.00 \pm 10.85$ & $1.07 \pm 0.31$ & $8.05 \pm 1.11$ & $2.35 \pm 0.28$ & $82.48 \pm 10.65$ \\
\hline Unharvested $\left(\mathrm{Mg} \mathrm{C} \mathrm{ha}^{-1}\right)$ & $96.03 \pm 8.96$ & $1.86 \pm 0.58$ & $5.33 \pm 1.68$ & $1.06 \pm 0.10$ & $104.28 \pm 9.14$ \\
\hline$\%$ difference & $-32.46 \pm 0.10$ & $-45.59 \pm 0.46$ & $50.51 \pm 0.36$ & $73.54 \pm 0.11$ & $-25.13 \pm 0.07$ \\
\hline \multicolumn{6}{|l|}{ Bioenergy WTH } \\
\hline Harvested $\left(\mathrm{Mg} \mathrm{C} \mathrm{ha}^{-1}\right)$ & $57.30 \pm 3.12$ & $0.86 \pm 0.15$ & $6.26 \pm 0.52$ & $2.00 \pm 0.23$ & $69.09 \pm 3.49$ \\
\hline Unharvested $\left(\mathrm{Mg} \mathrm{C} \mathrm{ha}^{-1}\right)$ & $86.73 \pm 3.15$ & $1.56 \pm 0.23$ & $6.44 \pm 0.60$ & $1.31 \pm 0.10$ & $98.10 \pm 2.80$ \\
\hline$\%$ difference & $-42.41 \pm 0.05$ & $-61.75 \pm 0.19$ & $-2.14 \pm 0.13$ & $36.95 \pm 0.11$ & $-36.33 \pm 0.04$ \\
\hline \multicolumn{6}{|l|}{ Bioenergy non-WTH } \\
\hline Harvested (Mg C ha $\left.{ }^{-1}\right)$ & $85.48 \pm 4.84$ & $0.75 \pm 0.25$ & $9.92 \pm 2.03$ & $2.15 \pm 0.33$ & $103.42 \pm 4.95$ \\
\hline Unharvested $(\mathrm{Mg} \mathrm{C} \mathrm{ha-1)}$ & $120.04 \pm 15.06$ & $3.41 \pm 1.05$ & $6.52 \pm 1.16$ & $1.32 \pm 0.10$ & $142.75 \pm 8.63$ \\
\hline$\%$ difference & $-31.38 \pm 0.08$ & $-123.93 \pm 0.32$ & $37.11 \pm 0.26$ & $45.07 \pm 0.22$ & $-31.81 \pm 0.04$ \\
\hline
\end{tabular}


Table 5 Wilcoxon Signed Rank test results for comparing paired harvested and unharvested stands for the three types of harvests for each of the forest stand $\mathrm{C}$ pools. The results for all the harvests combined are shown as well. Statistical significance is indicated in bold

\begin{tabular}{|c|c|c|c|c|c|c|}
\hline & & Live Tree & Snags & DCWD & FWD & TOTAL \\
\hline \multirow[t]{3}{*}{ Non-Bioenergy } & Test Statistic S & 10.50 & 4.50 & -5.50 & -10.50 & 10.50 \\
\hline & $\mathrm{df}$ & 5 & 5 & 5 & 5 & 5 \\
\hline & $P$-value & 0.02 & 0.22 & 0.31 & 0.03 & 0.02 \\
\hline \multirow[t]{3}{*}{ Bioenergy WTH } & Test Statistic S & 162.50 & 96.50 & 6.50 & -66.00 & 95.00 \\
\hline & $\mathrm{df}$ & 24 & 24 & 24 & 18 & 18 \\
\hline & $P$-value & $<0.0001$ & 0.003 & 0.87 & 0.01 & $<0.0001$ \\
\hline \multirow[t]{3}{*}{ Bioenergy non-WTH } & Test Statistic S & 5.00 & 5.00 & -3.00 & -3.00 & 3.00 \\
\hline & $\mathrm{df}$ & 3 & 3 & 3 & 2 & 2 \\
\hline & $P$-value & 0.06 & 0.06 & 0.38 & 0.25 & 0.13 \\
\hline \multirow[t]{3}{*}{ All Harvests } & Test Statistic S & 10.68 & 3.70 & -0.93 & -4.57 & 13.05 \\
\hline & $\mathrm{df}$ & 34 & 34 & 34 & 27 & 27 \\
\hline & $P$-value & $<0.0001$ & 0.0002 & 0.43 & $<0.0001$ & $<0.0001$ \\
\hline
\end{tabular}

as the change in total aboveground $\mathrm{C}$ revealed no statistically significant difference between the three types of harvest $(P>0.05)$. Although not statistically significant, the percent difference in some aboveground $C$ pools was greater for bioenergy WTH than the other types of harvests (Table 4). The magnitude of change in aboveground live tree C was greater $(-42.4 \%)$ for bioenergy WTH than for nonbioenergy (-32.5\%) and bioenergy non-WTH $(-31.4 \%)$. As already mentioned, bioenergy WTH had lower snag $\mathrm{C}$ pool postharvest with a decrease of $61.8 \%$. Furthermore, bioenergy WTH also had a smaller increase in FWD C (37.0\%) and the only decrease in DCWD C $(-2.1 \%)$ of any type of harvest. Bioenergy non-WTH and nonbioenergy sites had an increase in DCWD C of $37.1 \%$ and $50.5 \%$, respectively. The total decrease in aboveground $\mathrm{C}$ was greater for bioenergy WTH sites $(-36.3 \%)$ than bioenergy nonWTH $(-31.8 \%)$ and nonbioenergy $(-25.1 \%)$ harvests (Table 4).

\section{Emissions from energy production and $C$ in wood products}

All of the bioenergy produced from the harvests and evaluated in this study was derived from woodchips. The percent bioenergy by volume of the total product ranged from 5 to $99 \%$. Most of the bioenergy went to utility-scale bioenergy power plants around the U.S. Northeast (83\%) including: the 50 megawatt (MW) McNeil Generating Station in Burlington, VT, USA; the 20 MW Ryegate Power Station in Ryegate, VT, USA; the 16 MW Whitefield Power and Light Biomass Plant in Whitefield, NH, USA; the 15 MW Pinetree Power Biomass Plant in Bethlehem, NH, USA; with some bioenergy possibly going to the other $20 \mathrm{MW}$ Pinetree Power Biomass Plant in Tamworth, NH, USA. Some bioenergy went to heat local schools $(7 \%)$, and the remainder to combined heat and power at pulp and paper mills (10\%; Table 2).

On average, bioenergy WTH produced about 51\% bioenergy by volume, whereas bioenergy non-WTH produced only $10 \%$. This higher allocation of harvested wood to bioenergy rather than wood products resulted in higher emissions, especially from electricity, than those from bioenergy non-WTH sites (Fig. 3). The emissions from thermal energy generation $\left(0.19 \mathrm{Mg} \mathrm{C}^{-1}\right)$ and combined heat and power $\left(0.58 \mathrm{Mg} \mathrm{C}^{-1}\right)$ were $69 \%$ and $22 \%$ less than those from electricity (13.52 $\mathrm{Mg} \mathrm{C} \mathrm{ha}{ }^{-1}$ ), respectively. We found a statistically significant difference in net emissions between the types of bioenergy harvest based on the results of the Wilcoxon Rank Sum test. Emissions from bioenergy WTH were significantly higher $(P<0.01)$ compared with bioenergy non-WTH. As the bioenergy WTH yielded more volume for bioenergy production than bioenergy nonWTH, they also resulted in more savings from the avoided burning of fossil fuels. Based on the emission factors and energy generation efficiencies for various end-uses of fossil fuels (Table 3), the bioenergy WTH harvests averaged fossil fuel offsets $2.83 \mathrm{Mg} \mathrm{C} \mathrm{ha}^{-1}$, whereas bioenergy non-WTH had savings of $0.53 \mathrm{Mg} \mathrm{C} \mathrm{ha}{ }^{-1}$ from both direct and indirect fossil fuel avoided emissions $(P<0.01$; Fig. 3$)$.

The bioenergy non-WTH harvests generated fewer emissions (3.87 $\mathrm{Mg} \mathrm{C}^{-1}$ direct and $0.19 \mathrm{Mg} \mathrm{C}^{-1}$ indirect emissions) from energy generation than bioenergy WTH $\left(19.40 \mathrm{Mg} \mathrm{C} \mathrm{ha}^{-1}\right.$ from direct and $0.97 \mathrm{Mg} \mathrm{C} \mathrm{ha}{ }^{-1}$ from indirect emissions; Fig. 3). Bioenergy non-WTH practices also left more $\mathrm{C}$ stored in the stand (103.42 $\mathrm{Mg} \mathrm{C} \mathrm{ha}^{-1}$ ) and in wood products postharvest (19.27 $\mathrm{Mg} \mathrm{C} \mathrm{ha}^{-1}$ ) than bioenergy WTH (Fig. 3). Bioenergy WTH sites had an average of $69.09 \mathrm{Mg} \mathrm{C}^{-1}$ residual in forest stands and $10.95 \mathrm{Mg} \mathrm{C} \mathrm{ha}^{-1}$ in wood products (Fig. 3). Of the 35 sites we inventoried, all 

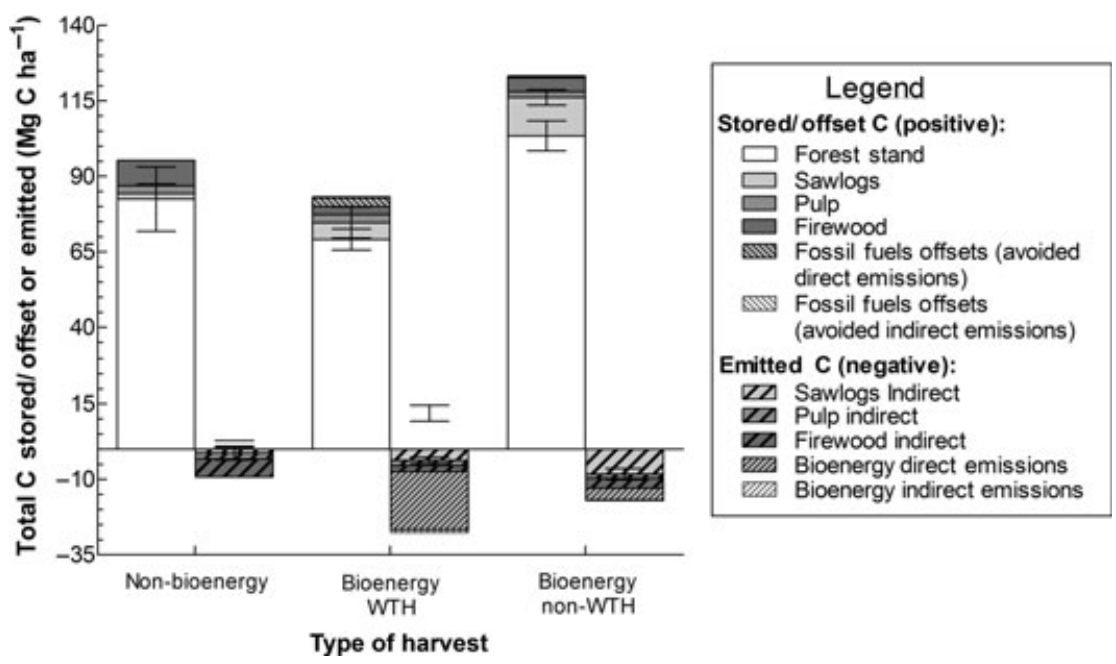

Fig. 3 Total mean carbon $\left(\mathrm{Mg} \mathrm{C} \mathrm{ha}{ }^{-1}\right)$ in harvested stands by harvest type. The $\mathrm{C}$ per ha is shown for the measured forest stand pools, $\mathrm{C}$ transferred to wood products by wood product type, emissions from the generation of each of those wood products, emissions for bioenergy productions, and avoided emissions from fossil fuel offsets. The error bars indicate total SE for the total forest C, wood products, and energy emissions.

generated sawlogs, almost half (46\%) produced pulp as a product, 28 produced firewood, 3 produced pallet, and 2 produced veneer. Bioenergy non-WTH harvests had more $C$ transferred to sawlogs than either the bioenergy WTH or nonbioenergy harvests $(P<0.05)$. Bioenergy WTH had less $\mathrm{C}$ in firewood than nonbioenergy harvests $(P<0.05)$. Although there was no statistically significant difference between $C$ transferred to pulp for any of the harvesting categories $(P=0.85)$, the total $C$ transferred to wood products and emitted from harvesting, transporting, and processing wood products was significantly higher $(P<0.05)$ for bioenergy non-WTH than for bioenergy WTH harvests.

\section{Effects of harvesting on net $C$ fluxes}

There were statistically significant differences in net C flux between harvest types based on our analysis using the percent difference metric (Eqn 2). The mean percent difference in net $\mathrm{C}$ flux was $-62 \%$ for bioenergy WTH, $-29 \%$ for bioenergy non-WTH, and $-20 \%$ for nonbioenergy. The post hoc multiple comparisons showed that, on average, bioenergy WTH had a larger flux of C than both bioenergy non-WTH and nonbioenergy harvests $(P<0.01)$.

Furthermore, our dataset showed evidence of wide variability among sites in terms of harvesting effects on C pools. Specifically, a Kruskal-Wallis test revealed that the variances between types of harvests were statistically significant different from each other $(H=12.88$; $\mathrm{df}=2 ; P<0.01)$. This range of variability in percent difference in net $C$ flux was significantly wider (standard deviation, $\mathrm{SD}=0.32 \mathrm{Mg} \mathrm{C} \mathrm{ha}^{-1}$ ) for bioenergy WTH harvests than for the other treatments (nonbioenergy $\mathrm{SD}=0.15 \mathrm{Mg} \mathrm{C} \mathrm{ha}{ }^{-1}$; bioenergy non-WTH $\mathrm{SD}=0.07$ $\mathrm{Mg} \mathrm{C} \mathrm{ha}{ }^{-1}$ ). The percent difference in total $\mathrm{C}$ flux ranged from -142 to $-11 \%$ for bioenergy $\mathrm{WTH},-44 \%$ to $-7 \%$ for nonbioenergy, and $-35 \%$ to $-21 \%$ for bioenergy non-WTH sites. A Wilcoxon Rank Sum test attributed the significant difference in percent difference net $C$ flux to the comparison of sites with and without WTH.

Treating firewood as bioenergy instead of a wood product did not change our fundamental conclusions. However, as expected, it did alter the bioenergy and wood product $\mathrm{C}$ flux results between types of harvests. With firewood excluded from the wood products pool, the amount of $\mathrm{C}$ transferred to wood products, and the subsequent indirect emissions, were significantly higher for bioenergy non-WTH harvests than for nonbioenergy harvests $(P<0.05)$. There was no statistically significant difference between $\mathrm{C}$ in wood products at bioenergy WTH sites and the other two types of harvests $(P>0.05)$. Furthermore, accounting for firewood as bioenergy with the woodchip emissions resulted in no statistically significant difference between types of harvests for $\mathrm{C}$ flux from bioenergy or the avoided emissions fossil fuel offsets from using bioenergy and firewood instead $(P>0.05)$. Despite these changes in allocation of $C$ to different end-uses, our conclusions about percent difference in total $\mathrm{C}$ flux did not change. Bioenergy WTH sites still had a greater net flux of $C$ than both bioenergy non-WTH and nonbioenergy sites $(P<0.05)$. There was no statistically significant difference between net $C$ flux from nonbioenergy and bioenergy non-WTH sites $(P=1.00)$. 


\section{Influence of multiple predictors on C outcomes}

The CART analysis did not select harvesting type (e.g. bioenergy vs. nonenergy or WTH) as the best predictor of net $C$ flux. Instead the analysis indicated that the strongest predictor for the sites we sampled was the type and size of skidding machinery (Fig. 4). Specifically, harvests where a grapple skidder [Fig. 1; e.g. CAT 535B (Caterpillar, Peoria, IL, USA) or John Deere $648 \mathrm{H}$ model (John Deere, Moline, IL, USA)] was used had a larger total net flux of C (Eqn 2) postharvest than those employing a bulldozer/forwarder, a cable skidder [e.g. John Deere JD 540G-III model (John Deere, Moline, IL, USA)], and/or a grapple skidder. This is evident in the CART results, where skidder type was the top ranked independent variable associated with the first partition of the dependent variable (Fig. 4). Moving down the regression tree, two variables emerged as most predictive of the second tier partitions in total net $C$ flux. These were primary silvicultural treatment and type of felling equipment.

Felling equipment type also explained deviance in the total $\mathrm{C}$ flux postharvest, at levels less than those associated with silvicultural treatment. Net C flux was more intense from harvests employing only a tree shear or mechanized harvester compared with harvests using only chainsaws (i.e. hand felling) or a combination of chainsaws and mechanized harvesting (Fig. 4). The greatest overall net $\mathrm{C}$ flux was associated with the combination of grapple skidding and more intensive silvicultural treatments, whereas the lowest $C$ fluxes occurred at sites where hand felling was used in conjunction with cable-skidders, or bulldozers and forwarders.

\section{Discussion}

An on-going debate has focused on whether bioenergy harvesting will result in lower landscape $C$ storage with an associated increased $C$ flux to the atmosphere, with some scientists arguing this as likely (Fargione et al., 2008; Gunn et al., 2012) and others arguing it as not (Malmsheimer et al., 2011). Our study suggests the answer may depend on a variety of factors. In reporting data on the immediate postharvest emissions associated with bioenergy harvesting, we add to a developing understanding of C dynamics associated with forest management, including impacts on in situ aboveground forest C storage and wood products pools (Harmon \& Marks, 2002; Swanson, 2009; Nunery \& Keeton, 2010), product substitution effects (Eriksson et al., 2007; Mckechnie et al., 2011), and energy offsets (Searchinger et al., 2009; Mckechnie et al., 2011).

There was insufficient evidence in our dataset to conclude generally that an increase in bioenergy harvesting in the northeastern U.S. will result in an intensification of management with associated increases in net $C$ fluxes. Instead the results tell a more nuanced story.

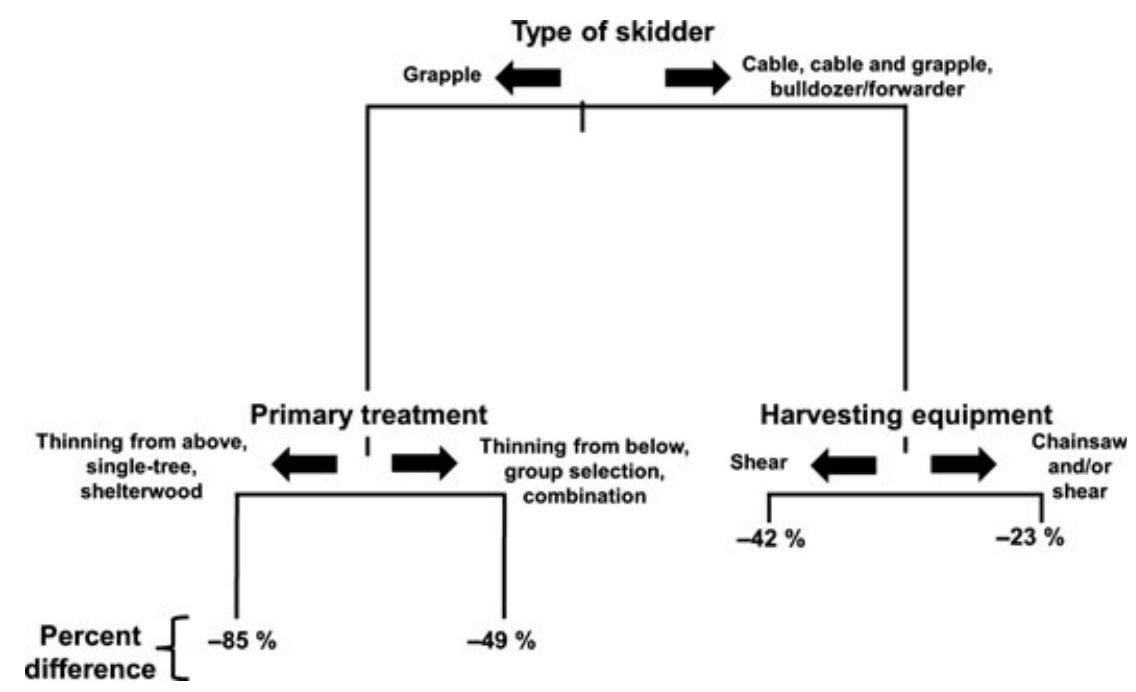

Fig. 4 Classification and Regression Tree (CART) analysis on percent difference in total net C flux comparing unharvested to harvested sites. The CART ranks the independent variable based on predictive power with the variable that explains the highest amount of variance in the dependent variable on top. The size of the branch (vertical lines) shows the amount of deviance explained by the independent variable at the top of the split and the length of the node (horizonal lines) illustrates the total sum of squares explained by the split. The independent variables used in the CART analysis are those from Table 2 . In CART, $n$ is calculated by multiplying the number of observations $(n=28)$ by the number of levels of the variable that explains the largest amount of variance $(n=4)$. Minimum number of observations used before split $=5$; minimum node size $=10$; minimum deviance required before split $=0.01$; $n=112$. 
Our results indicate that bioenergy harvests are highly variable in net $\mathrm{C}$ emissions. WTH sites, specifically, had larger variability in percent difference of net $C$ flux than the other two types of harvests. Other researchers have produced similar findings in terms of impacts on stand structure and habitat characteristics (Littlefield \& Keeton, In Press). Much of this variability appears strongly related to silvicultural treatment and operational variables, which may drive the intensity of the harvest, rather than the volume allocated to energy generation specifically.

The CART analysis clearly showed that operational variables, particularly skidder type, were strongly predictive of net $C$ flux, which relates to efficiency of volume removal and associated reductions in residual stand structure. Grapple skidders and more intensive silvicultural treatments were, in turn, positively correlated with WTH. For example, WTH operations employed grapple skidders at $76 \%$ of the sites we sampled, whereas only $30 \%$ of the non-WTH sites (both with and without bioenergy) used grapple skidders (Table 6). Whether or not bioenergy harvests incorporated WTH also had a strong and positive effect on net $\mathrm{C}$ emissions based on the categorical comparisons; net $\mathrm{C}$ flux from WTH was twice as large as for the other treatments. These general contrasts between WTH and non-WTH sites held both with and without the

Table 6 Number of sites and percent of subtotal using different types of skidder and cutting equipment for bioenergy WTH, bioenergy non-WTH, and non-bioenergy harvests

\begin{tabular}{|c|c|c|c|}
\hline & $\begin{array}{l}\text { Bioenergy } \\
\text { WTH }\end{array}$ & $\begin{array}{l}\text { Bioenergy } \\
\text { non-WTH }\end{array}$ & Nonbioenergy \\
\hline \multicolumn{4}{|l|}{ Grapple skidder } \\
\hline Shear & 13 & - & 1 \\
\hline Chainsaw & - & - & - \\
\hline Shear and chainsaw & 1 & - & - \\
\hline Total $\%$ & 56.0 & 0.0 & 16.7 \\
\hline \multicolumn{4}{|l|}{ Cable skidder } \\
\hline Shear & 1 & - & - \\
\hline Chainsaw & 3 & 1 & 3 \\
\hline Shear and chainsaw & 2 & - & - \\
\hline Total\% & 24.0 & 25.0 & 50.0 \\
\hline \multicolumn{4}{|c|}{ Both cable and grapple skidder } \\
\hline Shear & 4 & - & 1 \\
\hline Chainsaw & 1 & 1 & - \\
\hline Shear and chainsaw & - & - & - \\
\hline Total $\%$ & 20.0 & 25.0 & 16.7 \\
\hline \multicolumn{4}{|c|}{ None (bulldozer/forwarder only) } \\
\hline Shear & - & - & - \\
\hline Chainsaw & - & - & 1 \\
\hline Shear and chainsaw & - & 2 & - \\
\hline Total $\%$ & 0.0 & 50.0 & 16.7 \\
\hline
\end{tabular}

inclusion of emissions from firewood. Consequently, we can infer that greater use of WTH would intensify biomass removals and net $\mathrm{C}$ fluxes. Our data did not support a general conclusion that generating multiple products including bioenergy, removing low grade stems, but leaving tops in the forests, are likely to result in a significant increase in net $\mathrm{C}$ flux immediately postharvest.

\section{Harvesting effects on dead C pools}

Our data showed wide variability both within and between types of harvest in terms of removals of dead wood and residues. However, postharvest decreases in snag and DCWD $\mathrm{C}$ were most pronounced for WTH operations, showing decreases, whereas bioenergy nonWTH and nonbioenergy harvests showed increases. These results were not statistically significant due to variability within treatment groups and widely unequal sample sizes. Variability in DCWD retention levels and spatial distribution is common for both bioenergy and nonbioenergy harvests (Grushecky et al., 2006; Briedis et al., 2011b). DCWD is often left both scattered and clumped (Harmon et al., 1986), with as much as $16-50 \%$ of all downed wood (FWD and DCWD) piled on skid trails, often deliberately to reduce soil impacts (Briedis et al., 2011b). Skid trails can cover up to $15 \%$ of the harvested stand area (Briedis et al., 2011b). Although we avoided sampling major skid roads in this study, we included smaller skid trails, which may have contributed to some of the variability we observed in volumes of DCWD between sites. Finally, bioenergy WTH was the only treatment that had a statistically significant decrease in snag $C$ postharvest, whereas the other treatments showed greater variability in snag $\mathrm{C}$ postharvest relative to reference sites. This indicates that WTH operations may be more likely to reduce snag abundance, perhaps due to the use of larger equipment.

Despite variation in harvesting approaches and site conditions, several other clear trends emerged. The bioenergy non-WTH had the highest C levels in DCWD and FWD pools immediately postharvest, likely due to more tree tops retained on site. At nonbioenergy sites, total DCWD and FWD C ranged from 10.9 to $13.2 \%$ of total aboveground $\mathrm{C}$ in harvested stands; the range was 5.4-8.0\% for unharvested reference stands. These numbers compare to those reported by Keeton et al. (2011) for unmanaged, late-successional northern hardwoodconifer forests, in which DCWD represented $10-11 \%$ of total aboveground $\mathrm{C}$. The comparison suggests that slash and unmerchantable stem retention maintains a DCWD pool, proportionate to total stand C, either equal to or exceeding natural baselines, although volume in absolute terms is often significantly lower in managed stands (Mcgee et al., 1999). Effects of harvesting on 
woody debris are important not only because of C storage but also because of functions performed by DCWD. Those include providing wildlife habitat, reducing soil erosion, enhancing soil moisture retention, cycling nutrients, and providing riparian functions (Harmon et al., 1986; Keeton et al., 2007; Evans \& Ducey, 2010). Our data suggest that some bioenergy logging operations in the U.S. Northeast are either leaving adequate DCWD on site or are adding additional pieces during the harvest, although practices and retention levels vary widely. Thus, there is a role for harvesting guidelines intended to encourage wider adoption of retention practices that would maintain greater $\mathrm{C}$ storage on site, in effect setting the bar where it is already being met by some operators, as supported by our data.

\section{Uncertainties in assessing C emissions from bioenergy harvests}

Some have argued that because burning wood releases more greenhouse gasses per unit of energy produced than fossil fuels, greater reliance on wood bioenergy will create an initial C 'debt' that must be compensated over time both by forest regrowth and avoided fossil fuel emissions (a 'dividend'; Searchinger et al., 2009). Others have commented that the magnitude of $\mathrm{C}$ debt and timelag until dividend depends on the end-use of the bioenergy (Eriksson et al., 2007; Zanchi et al., 2011). More recently, a view has emerged that $C$ debt can be avoided if lowered landscape C stocks in some stands (and associated emissions from bioenergy) are compensated by sequestration in others (Malmsheimer et al., 2011). This paradigm underpins the U.S. Environmental Protection Agency's (EPA's) current framework for accounting for bioenergy emissions (EPA, 2011). Immediately postharvest, we found that in all bioenergy harvesting scenarios, the $\mathrm{C}$ removed from stands and emitted from bioenergy generation was greater compared with equal amounts of energy produced from fossil fuels. These results were consistent with Mckechnie et al. (2011).

In our view, the critical first step needed to resolve this debate is a determination of whether bioenergy harvests are likely to intensify $C$ removals. If so, they would lower the average amount of $C$ stored on the landscape at any point in time, thereby, representing a semipermanent $\mathrm{C}$ flux to the atmosphere. Other researchers have found that the source of bioenergy and the time scale of the analysis impact the net $\mathrm{C}$ flux, with greater emissions from bioenergy in the short-term (Zanchi et al., 2011). In our study, WTH intensified $C$ removals and resulted in greater net emissions compared with other types of harvesting. This finding challenges the assumption that landscape C stocks will remain constant as demand for bioenergy increases, particularly if the industry moves to greater reliance on WTH methods. However, net emissions from WTH also were significantly more variable compared with other harvesting approaches, suggesting that emissions outcomes will depend to a large degree on operational variables, attention given to structural retention, and other site-specific considerations. Understanding the net effects of bioenergy harvests on $\mathrm{C}$ emissions will require accounting for forest $\mathrm{C}$ inputs and outputs over multiple harvest rotations. It will also necessitate accounting at temporal and spatial scales sufficiently large to capture landscape-scale C dynamics, particularly those associated with many different harvests staggered over time and space (Schlamadinger \& Marland, 1999; Searchinger et al., 2009; Manomet Center for Conservation Sciences, 2010; Gunn et al., 2012).

We evaluated the C impact of bioenergy harvests in the northeastern U.S. where forest type and specific silvicultural treatments, including harvesting equipment, may differ from other parts of the country and the world. However, the underlying questions about intensification of harvesting for bioenergy production are globally applicable. Researchers have already pointed out substantial C-accounting errors associated with the assumption that bioenergy is C-neutral (Johnson, 2009; Searchinger et al., 2009). The impact of bioenergy harvesting on short- and intermediate-term $\mathrm{C}$ flux has also been studied in Europe (Zanchi et al., 2011). In Austria, researchers concluded that there is a high risk of increased net $\mathrm{C}$ flux if additional fellings are used for bioenergy generation when the total volume allocated to bioenergy is low (Zanchi et al., 2011). Our study supports these findings and adds that the driver behind an increased net $\mathrm{C}$ flux from bioenergy harvests in the Northeastern U.S. is likely the use of heavier machinery associated with WTH.

\section{Implications for bioenergy harvesting and C-accounting}

Although atmospheric $C$ reductions may be achieved in the long-term through sustainable forest management that increase $C$ stored in standing forests and durable wood products (Liu \& Han, 2009), our results suggest allocating more volume to energy generation than wood products may have a larger initial flux of $C$ than those that generate more wood products. Durable wood products, such as furniture or construction grade lumber, represent an important $\mathrm{C}$ pool that can store C for decades (Malmsheimer et al., 2008), although there are losses associated with their conversion and the stores decline over time (Smith et al., 2006). Decisions regarding whether to allocate harvested material to bioenergy vs. competing products and uses will be heavily dependent on future market 
prices for chips as well as sawlogs and pulp fiber (Eisenbies et al., 2009; Briedis et al., 2011a).

Our results showed that the machinery used during the harvests had the largest influence on net C flux. In our sample, WTH sites were more likely to use heavier machinery, such as a grapple skidder, than harvests that did not use whole-tree harvesting. The move from harvesting practices using chainsaws, cable-skidders, bulldozers, and tractors to feller-bunchers and cutto-length systems with forwarders, clambunk, and grapple skidders may be increasingly profitable because it improves operational efficiency (Ledoux, 2010). Bioenergy operations, in particular, gain economies of scale through mechanized harvesting, because it allows efficient harvesting of low grade/low value material across larger areas (Goychuk et al., 2011; Munsell et al., 2011). The trend toward heavier machinery, particularly grapple skidders, is reflected in our dataset, with most $(63 \%)$ of the harvests employing a grapple skidder. Bigger machines open up more and wider travel lanes (Goychuk et al., 2011), contributing to the reductions in residual stand structure and aboveground C pools seen in our dataset. Thus, our findings strongly suggest that increased, continued investment in larger, mechanized machinery is likely to accelerate $\mathrm{C}$ removals and postharvest $\mathrm{C}$ emissions associated with bioenergy harvesting.

Finally, our conclusion that WTH may decrease certain aboveground $\mathrm{C}$ pools more than other harvesting approaches has implications for sustainable forest management, particularly where minimization of net $\mathrm{C}$ emissions is a key objective. As WTH may decrease snag and DCWD more than non-WTH methods, we suggest that foresters carefully consider structural retention when using these methods. This includes leaving a portion of tops on site and retaining snags whenever safety considerations allow.

\section{Acknowledgements}

This research was supported by grants from the National Science Foundation (Award \#0613884), the Northeastern States Research Cooperative, and the USDA McIntire-Stennis Forest Research Program. We thank Don Tobi and many other foresters in VT, NH, and NY who helped locate properties for sampling, showed us around, and provided us with useful information. We also thank the landowners for allowing us access to their properties. We are grateful to our summer field crew Isabel Beavers, Emily Potter, and especially Caitlin Littlefield. We thank UVM's Carbon Dynamics Lab, GEOL 371 class, and 3 anonymous reviewers who provided valuable feedback on an early version of this manuscript.

\section{References}

American Carbon Registry (2010) Forest Carbon Project Standard Version 2.1. American Carbon Registry, Arlington, Virginia, USA.
Birdsey RA (1992) Carbon Storage and Accumulation in United States Forest Ecosystems. Department of Agriculture, Forest Service, Washington, DC, USA.

Briedis JI, Wilson JS, Benjamin Jeffrey G, Wagner RG (2011a) Biomass retention following whole-tree, energy wood harvests in central Maine: adherence to five state guidelines. Biomass and Bioenergy, 35, 3552-3560.

Briedis JI, Wilson JS, Benjamin JG, Wagner RG (2011b) Logging residue volumes and characteristics following integrated roundwood and energy-wood whole-tree harvesting in central Maine. Northern Journal of Applied Forestry, 28, 66-71.

California Air Resources Board (2010) Local Government Operations Protocol for the Quantification and Reporting of Greenhouse gas Emissions Inventories Version 1.1. California Air Resources Board, California Climate Action Registry, ICLEI - Local Governments for Sustainability, and The Climate Registry, Sacramento, CA.

Davis SC, Hessl AE, Scott CJ, Adams MB, Thomas RB (2009) Forest carbon sequestration changes in response to timber harvest. Forest Ecology and Management, 258, 2101-2109.

De'ath G, Fabricius KE (2000) Classification and Regression Trees: a powerful yet simple technique for ecological data analysis. Ecology, 81, 3178-3192.

Demirbas A (2001) Biomass resource facilities and biomass conversion processing for fuels and chemicals. Energy Conversion and Management, 42, 1357-1378.

Eisenbies M, Vance E, Aust W, Seiler J (2009) Intensive utilization of harvest residues in southern pine plantations: quantities available and implications for nutrient budgets and sustainable site productivity. BioEnergy Research, 2, 90-98.

EPA (2011) Accounting Framework for Bioenenic $\mathrm{CO}_{2}$ Emissions From Stationary Sources. U.S. Environmental Protection Agency, Office of Atmospheric Programs, Climate Change Division, Washington, DC, USA.

Eriksson E, Gillespie AR, Gustavsson L, Langvall O, Olsson M, Sathre R, Stendahl J (2007) Integrated carbon analysis of forest management practices and wood substitution. Canadian Journal of Forest Research, 37, 671-681.

Evans AM, Ducey MJ (2010) Carbon Accounting and Management of Lying Dead Wood. Forest Guild, Santa Fe, New Mexico, USA.

Evans AM, Finkral AJ (2009) From renewable energy to fire risk reduction: a synthesis of biomass harvesting and utilization case studies in US forests. GCB Bioenergy, 1, 211-219.

Fargione J, Hill J, Tilman D, Polasky S, Hawthorne P (2008) Land clearing and the biofuel carbon debt. Science, 319, 1235-1238.

Forster P, Ramaswamy V, Artaxo P et al. (2007) Changes in atmospheric constituents and in radiative forcing. In: Climate Change 2007: The Physical Science Basis. Contribution of Working Group I to the Fourth Assessment Report of the Intergovernmental Panel on Climate Change (eds Solomon S, Qin D, Manning M, Chen Z, Marquis M, Averyt KB, Tignor M, Miller HL), pp 129-234. Intergovernmental Panel on Climate Change, New York, New York, USA.

Fredeen AL, Bois CH, Janzen DT, Sanborn PT (2005) Comparison of coniferous forest carbon stocks between old-growth and young second-growth forests on two soil types in central British Columbia, Canada. Canadian Journal of Forest Research, 35, 1411-1421.

Goychuk D, Kilgore MA, Blinn CR, Coggins J, Kolka RK (2011) The effect of timber harvesting guidelines on felling and skidding productivity in northern Minnesota. Forest Science, 57, 393-407.

Grushecky ST, Mcgill DW, Anderson RB (2006) Inventory of wood residues in southern West Virginia. Northern Journal of Applied Forestry, 23, 47-52.

Gunn JS, Ganz DJ, Keeton WS (2012) Biogenic vs. geologic carbon emissions and forest biomass energy production. GCB Bioenergy, 4, 239-242.

Hall DO (1997) Biomass energy in industrialised countries - a view of the future. Forest Ecology and Management, 91, 17-45.

Hamilton K, Sjardin M, Peters-Stanley M, Marcello T (2010) Building Bridges: State of the Voluntary Carbon Markets 2010. A Report by Ecosystem Marketplace \& Bloomberg New Energy Finance. The Katoomba Groups' Ecosystem Marketplace, New York, NY and Washington, DC, USA.

Harmon ME (2001) Carbon sequestration in forests: addressing the scale question. Journal of Forestry, 99, 24-29.

Harmon ME, Marks B (2002) Effects of silvicultural practices on carbon stores in Douglas-fir - western hemlock forests in the Pacific Northwest, U.S.A.: results from a simulation model. Canadian Journal of Forest Research, 32, 863-877.

Harmon ME, Franklin JF, Swanson FJ et al. (1986) Ecology of coarse woody debris in temperate ecosystems. Advances in Ecological Research, 15, 133-302.

Harmon ME, Ferrell WK, Franklin JF (1990) Effects on carbon storage of conversion of old-growth forests to young forests. Science, 247, 699-702.

Harmon ME, Woodall CW, Fasth B, Sexton J (2008) Woody Detritus Density and Density Reduction Factors for Tree Species in the United States: A Synthesis. U.S. Department of Agriculture, Forest Service, Northern Research Station, Newtown Square, Pennsylvania, USA. 
Honer TG, Ker MF, Alemdag IS (1983) Metric Timber Tables for the Commercial Tree Species of Central and Eastern Canada. Maritime Forest Research Centre, Fredericton, New Brunswick, Canada.

Hoover C, Stout S (2007) The carbon consequences of thinning techniques: stand structure makes a difference. Journal of Forestry, 105, 266-270.

Hudiburg TW, Law BE, Wirth C, Luyssaert S (2011) Regional carbon dioxide implications of forest bioenergy production. Nature Climate Change, 1, 419-423.

IPCC (2007) Summary for policymakers. In: Climate Change 2007: The Physical Science Basis. Contribution of Working Group I to the Fourth Assessment Report of the Intergovernmental Panel on Climate Change (eds Solomon S, Qin D, Manning M, Chen Z, Marquis M, Averyt KB, Tignor M, Miller HL), pp. 1-18. Intergovernmental Panel on Climate Change, New York, New York, USA.

Jandl R, Lindner M, Vesterdal L et al. (2007) How strongly can forest management influence soil carbon sequestration? Geoderma, 137, 253-268.

Jenkins JC, Chojnacky DC, Heath LS, Birdsey RA (2003) National-scale biomass estimators for United States tree species. Forest Science, 49, 12-35.

Johnson E (2009) Goodbye to carbon neutral: getting biomass footprints right. Environmental Impact Assessment Review, 29, 165-168.

Johnson DW, Curtis PS (2001) Effects of forest management on soil C and N storage: meta analysis. Forest Ecology and Management, 140, 227-238.

Keeton WS (2006) Managing for late-successional/old-growth characteristics in northern hardwood-conifer forests. Forest Ecology and Management, 235, 129-142.

Keeton WS, Franklin JF (2005) Do remnant old-growth trees accelerate rates of succession in mature Douglas-fir forests? Ecological Monographs, 75, 103-118.

Keeton WS, Kraft CE, Warren DR (2007) Mature and old-growth riparian forests: structure, dynamics, and effects on Adirondack stream habitats. Ecological Applications, 17, 852-868.

Keeton WS, Whitman AA, Mcgee GC, Goodale CL (2011) Late-successional biomass development in northern hardwood-conifer forests of the northeastern United States. Forest Science, 57, 489-505.

Kroetz KM, Friedland AJ (2008) Comparing costs and emissions of northern New England space heating fuel options. Biomass and Bioenergy, 32, 1359-1366.

Lamsal S, Cobb RC, Hall Cushman J, Meng Q, Rizzo DM, Meentemeyer RK (2011) Spatial estimation of the density and carbon content of host populations for Phytophthora ramorum in California and Oregon. Forest Ecology and Management, 262, 989-998.

Lattimore B, Smith CT, Titus BD, Stupak I, Egnell G (2009) Environmental factors in woodfuel production: Opportunities, risks, and criteria and indicators for sustainable practices. Biomass and Bioenergy, 33, 1321-1342.

Ledoux CB (2010) Mechanized Systems for Harvesting Eastern Hardwoods. Department of Agriculture, Forest Service, Northern Research Station, Newtown Square, Pennsylvania, USA.

Lippke B, Gustafson R, Venditti R et al. (2011) Sustainable biofuel contributions to carbon mitigation and energy independence. Forests, 2, 861-874.

Littlefield CE, Keeton WS (In Press) Effects of wood bioenergy harvesting on ecologically important stand structure characteristics in northern hardwood forests. Ecological Applications.

Liu G, Han S (2009) Long-term forest management and timely transfer of carbon into wood products help reduce atmospheric carbon. Ecological Modelling, 220, 1719-1723.

Malmsheimer RW, Heffernan P, Brink S et al. (2008) Forest management solutions for mitigating climate change in the United States. Journal of Forestry, 106, 115-118.

Malmsheimer RW, Bowyer JL, Fried JS et al. (2011) Managing forests because carbon matters: integrating energy, products, and land management policy. Journal of Forestry, 109, S7-S51(45).

Manomet Center for Conservation Sciences (2010) Massachusetts biomass sustainability and carbon policy study: report to the Commonwealth of Massachusetts Department of Energy Resources (ed. Walker T). Manomet Center for Conservation Sciences, Brunswick, Maine, USA.

Mcgee GG, Leopold DJ, Nyland RD (1999) Structural characteristics of old-growth, maturing, and partially cut Northern hardwood forests. Ecological Applications, 9, 1316-1329.

Mckechnie J, Colombo S, Chen J, Mabee W, Maclean HL (2011) Forest bioenergy or forest carbon? Assessing trade-offs in greenhouse gas mitigation with woodbased fuels. Environmental Science \& Technology, 45, 789-795.

Munsell JF, Barrett SM, Bolding MC (2011) An exploratory study of biomass harvesting among logging firms in Virginia and North Carolina. Forest Science, 57, 427-434.

Nabuurs GJ, Masera O, Andrasko K et al. (2007) Forestry. In: Climate Change 2007: Mitigation. Contribution of Working Group III to the Fourth Assessment Report of the
Intergovernmental Panel on Climate Change (eds Metz B, Davidson OR, Bosch PR Dave R, Meyer LA), pp. 541-584. Intergovernmental Panel on Climate Change, New York, New York, USA.

Nave LE, Vance ED, Swanston CW, Curtis PS (2010) Harvest impacts on soil carbon storage in temperate forests. Forest Ecology and Management, 259, 857-866.

Nunery JS, Keeton WS (2010) Forest carbon storage in the northeastern United States: net effects of harvesting frequency, post-harvest retention, and wood products. Forest Ecology and Management, 259, 1363-1375.

Parikka M (2004) Global biomass fuel resources. Biomass and Bioenergy, 27, 613-620.

Rothschild SS, Quiroz C, Salhotra M, Diem A (2009) The Value of EGRID and EGRIDweb to GHG Inventories. U.S. Environmental Protection Agency, Washington, DC, USA.

Routa J, Kellomäki S, Kilpeläinen A, Peltola H, Strandman H (2011) Effects of forest management on the carbon dioxide emissions of wood energy in integrated production of timber and energy biomass. GCB Bioenergy, 3, 483-497.

Ryan MG, Harmon ME, Birdsey RA et al. (2010) A synthesis of the science on forests and carbon for U.S. forests. Issues in Ecology, 13, 1-16.

Sader SA, Legaard KR (2008) Inclusion of forest harvest legacies, forest type, and regeneration spatial patterns in updated forest maps: a comparison of mapping results. Forest Ecology and Management, 255, 3846-3856.

SAS Institute Inc (2010) JMP. SAS Institute Inc., Cary, NC, USA.

Schlamadinger B, Marland G (1999) Net effect of forest harvest on $\mathrm{CO}_{2}$ emissions to the atmosphere: a sensitivity analysis on the influence of time. Tellus B, 51, 314 325 .

Schulze E-D, Körner C, Law BE, Haberl H, Luyssaert S (2012) Large-scale bioenergy from additional harvest of forest biomass is neither sustainable nor greenhouse gas neutral. GCB Bioenergy, doi: 10.1111/j.1757-1707.2012.01169.x (Early View).

Searchinger TD, Hamburg SP, Melillo J et al. (2009) Fixing a critical climate accounting error. Science, 326, 527-528.

Smith JE, Heath LS, Skog KE, Birdsey RA (2006) Methods for Calculating Forest Ecosystem and Harvested Carbon With Standard Estimates for Forest Types of the United States. Department of Agriculture, Forest Service, Northeastern Research Station, Newtown Square, Pennsylvania, USA.

Sollins P (1982) Input and decay of coarse woody debris in coniferous stands in western Oregon and Washington. Canadian Journal of Forest Research, 12, 18-28.

Swanson ME (2009) Modeling the effects of alternative management strategies on forest carbon in the Nothofagus forests of Tierra del Fuego, Chile. Forest Ecology and Management, 257, 1740-1750.

TIBCO Software Inc (2008) S+. TIBCO Software Inc., Palo Alto, CA.

Townsend P (1996) Honer's Standard Volume Table Estimates Compared to Nova Scotia Stem Analysis. Forest Planning and Research Section, Forestry Division, Nova Scotia Department of Natural Resources, Truro, Nova Scotia, Canada.

Van Tuyl S, Law BE, Turner DP, Gitelman AI (2005) Variability in net primary production and carbon storage in biomass across Oregon forests - an assessmen integrating data from forest inventories, intensive sites, and remote sensing. Forest Ecology and Management, 209, 273-291.

Twery MJ, Knopp PD, Thomasma SA et al. (2005) NED-2: a decision support system for integrated forest ecosystem management. Computers and Electronics in Agriculture, 49, 24-43.

Vanguelova E, Pitman R, Luiro J, Helmisaari H-S (2010) Long term effects of whole tree harvesting on soil carbon and nutrient sustainability in the UK. Biogeochemistry, 101, 43-59.

Verified Carbon Standard (2010) Approved VCS Methodology VM0003 Version 1.0. Methodology for Improved Forest Management Through Extension of Rotation Age. Sectoral Scope 14. Verified Carbon Standard, Washington, DC.

Van Wagner CE (1968) The line intersect method in forest fuel sampling. Forest Science, 14, 20-26.

Westerling AL, Hidalgo HG, Cayan DR, Swetnam TW (2006) Warming and earlier spring increase western U.S. forest wildfire activity. Science, 313, 940943.

Woodall C, Williams M (2005) Sampling Protocol, Estimation, and Analysis Procedures for the Down Woody Materials Indicator of the FIA Program. Department of Agriculture, Forest Service, North Central Research Station, St. Paul, Minnesota, USA.

Yanai RD, Currie WS, Goodale CL (2003) Soil carbon dynamics after forest harvest: an ecosystem paradigm reconsidered. Ecosystems, 6, 197-212.

Zanchi G, Pena N, Bird N (2011) Is woody bioenergy carbon neutral? A comparative assessment of emissions from consumption of woody bioenergy and fossil fuel. GCB Bioenergy, doi: 10.1111/j.1757-1707.2011.01149.x (Early View). 